\section{Smooth Crabgrass and Goosegrass Control with Metamifop in Creeping Bentgrass}

\author{
Ethan T. Parker ${ }^{1}$, J. Scott McElroy ${ }^{2}$, and Michael L. Flessner ${ }^{3,4}$
}

AdDitional Index woRDs. Eluesine indica, Digitaria ischaemum, Agrostis stolonifera, aryloxyphenoxypropionate

Summary. Smooth crabgrass (Digitaria ischaemum) and goosegrass (Eleusine indica) are problematic weeds in creeping bentgrass (Agrostis stolonifera) because of limited herbicide options for postemergence (POST) control and turfgrass injury potential. Metamifop is a herbicide currently being considered for release to markets in the United States but information is lacking on the most effective rates and application timings for smooth crabgrass and goosegrass control in creeping bentgrass. Field trials were conducted in Auburn, AL in 2009 and 2013 to evaluate metamifop rates (200 to $800 \mathrm{~g} \cdot \mathrm{ha}^{-1}$ ) and single or sequential application timings compared with fenoxaprop ( 51 to $200 \mathrm{~g} \cdot \mathrm{ha}^{-1}$ ) at two different mowing heights. Metamifop applied twice and three times sequentially at $200 \mathrm{~g} \cdot \mathrm{ha}^{-1}$ provided the greatest smooth crabgrass $(>97 \%)$ and goosegrass $(>90 \%)$ control at rough $(11 / 2$ inch) and green $(1 / 8$ inch) mowing heights without unacceptable creeping bentgrass injury at 56 days after initial treatment. All treatments caused $<20 \%$ visible injury on creeping bentgrass at both mowing heights except the highest rate of metamifop. Smooth crabgrass control at the green mowing height was greater than at the rough mowing height, especially at lower metamifop rates with a single application.

S mooth crabgrass and goosegrass are problematic weeds in creeping bentgrass in the transition zone, an area that rests between the southern United States where warmseason grasses dominate, and the northern United States where coolseason grasses thrive. These weeds are able to survive low mowing heights, especially among cool-season grasses (Busey, 2003; Callahan, 1986). As herbicide-resistant populations of smooth crabgrass (e.g., quinclorac) and goosegrass (e.g., prodiamine and pendimethalin) increase and as cultural control methods can be ineffective in cool-season grasses, new herbicides will be needed to ensure future control (Busey, 2003; Callahan, 1986; Hart et al., 2004; Heap, 2015; Mudge et al., 1984).

Several herbicides have been registered for smooth crabgrass and goosegrass control in cool-season turfgrass (King, 1990; Parker et al., 1985). Fenoxaprop controls both crabgrass and goosegrass; however,

${ }^{1}$ Department of Plant Sciences, 2431 Joe Johnson Drive, University of Tennessee, Knoxville, TN 37996

${ }^{2}$ Department of Crop Soil and Environmental Sciences, 201 Funchess Hall, Auburn University, AL 36849

${ }^{3}$ Department of Plant Pathology, Physiology, and Weed Science, Virginia Polytechnic Institute and State University, Blacksburg, VA 24061

${ }^{4}$ Corresponding author. E-mail: jsm0010@auburn.edu past research has shown fenoxaprop to cause stunting and stand reduction in seedling tall fescue (Schedonorus arundinaceus), perennial ryegrass (Lolium perenne), and creeping bentgrass (Cudney et al., 1997; Dernoeden, 1987; Neal et al., 1990). Herbicidal control options of smooth crabgrass and goosegrass in creeping bentgrass also include quinclorac, siduron, and bensulide. However, previous research has shown stunting, thinning, or foliar phytotoxicity to both mature and immature cool-season turfgrasses including creeping bentgrass with varying rates and application timings of many of these herbicides as well (Busey, 2003; Cudney et al., 1997; Dernoeden, 1987; Mueller-Warrant, 1990; Neal et al., 1990; Warren et al., 1989). Currently, only bensulide and oxadiazon are explicitly registered for preemergence (PRE) smooth crabgrass and goosegrass control on creeping bentgrass putting greens (PBI/ Gordon Corp., 2009; Quali-Pro, 2013). Given these limited options for controlling grass weeds in creeping bentgrass, new herbicidal control options would be beneficial for sustainable management.

Metamifop is an arloxyphenoxypropionate (AOPP) herbicide that has reported herbicidal activity on smooth crabgrass and goosegrass with safety to creeping bentgrass. Metamifop is not currently registered in the United States, but is used for POST annual and perennial weed control in Asia and the Middle East. It is used in many turfgrass systems including parks, golf courses, and gardens (Flessner and McElroy, 2011; Hoyle et al., 2012; Kim et al., 2003a, 2003b; Post and Askew, $2010)$. It is also used in many cereal crops such as rice (Oryza sativa) for control of annual and perennial grass weeds at 100 to $200 \mathrm{~g} \cdot \mathrm{ha}^{-1}$ (Moon et al., 2007, 2010). Along with smooth crabgrass and goosegrass, metamifop has also controls over annual grass weeds such as barnyardgrass (Echinochloa crus-galli), while remaining less injurious to coolseason grasses (Flessner and McElroy, 2011; Kim et al., 2003b; Post and Askew, 2010). Post and Askew (2010) observed that metamifop at $300 \mathrm{~g} \cdot \mathrm{ha}^{-1}$ controlled smooth crabgrass while causing $<10 \%$ creeping bentgrass injury whereas comparable smooth crabgrass control with fenoxaprop completely killed creeping bentgrass putting greens.

Metamifop inhibits acetyl-CoA carboxylase (ACCase), the enzyme that catalyzes the first step in fatty acid synthesis for membranes and cell growth (Burton et al., 1987; Devine et al., 1993; Focke and Lichtenthaler, 1987; Senseman, 2007). Like other AOPP herbicides, metamifop does not affect eudicotyledonous plants because of limited activity against cytosolic, the prokaryotic ACCase (Burton et al., 1987; Senseman, 2007). It has been hypothesized that these differing activities of AOPP herbicides in cool-season grasses and the selectivity observed among grasses

\begin{tabular}{llll}
\hline $\begin{array}{l}\text { Units } \\
\begin{array}{l}\text { To convert U.S. to SI, } \\
\text { multiply by }\end{array}\end{array}$ & U.S. unit & SI unit & $\begin{array}{l}\text { To convert SI to U.S., } \\
\text { multiply by }\end{array}$ \\
\hline 0.3048 & $\mathrm{ft}$ & $\mathrm{m}$ & 3.2808 \\
9.3540 & gal $/ \mathrm{acre}$ & $\mathrm{L} \cdot \mathrm{ha}^{-1}$ & 0.1069 \\
2.54 & inch $(\mathrm{es})$ & $\mathrm{cm}$ & 0.3937 \\
25.4 & inch $(\mathrm{es})$ & $\mathrm{mm}$ & 0.0394 \\
70.0532 & oz/acre & $\mathrm{g} \cdot \mathrm{ha}^{-1}$ & 0.0143
\end{tabular}


may be because of an altered binding site within the ACCase target enzyme (Senseman, 2007; Stoltenberg et al., 1989). Irrespective of the specific mechanism, metamifop appears to be safer to cool-season turfgrasses while offering comparable control to other herbicides currently marked for crabgrass and goosegrass control (Cox and Askew, 2014; Flessner and McElroy, 2011; Kim et al., 2003a; Post and Askew, 2010).

The most efficacious rates and sequential application timings to achieve smooth crabgrass and goosegrass control have not been established. In addition, creeping bentgrass tolerance to metamifop at different mowing heights must be assessed. Research was conducted to evaluate metamifop rates and sequential application timings for smooth crabgrass and goosegrass control compared with an industry standard, fenoxaprop. The second objective was to evaluate creeping bentgrass injury associated with varying rates and application timings of metamifop at two mowing heights.

\section{Materials and methods}

Field research was conducted at the Auburn University Turfgrass Research and Education Center in Auburn, AL (lat. $32.34^{\circ} \mathrm{N}$, long. $85.29^{\circ} \mathrm{W}$ ) in 'Crenshaw' creeping bentgrass that has been established for greater than 5 years. Soil type was Marvyn Sandy Loam (fine-loamy, kaolinitic, thermic Typic Kanhapludult) with a $\mathrm{pH}$ of 6.0 and $1.1 \%$ organic matter. All trials were irrigated as needed to prevent drought stress. Three studies were conducted. Studies 1 and 2 evaluated smooth crabgrass control and creeping bentgrass injury at two mowing heights- $-1 / 8$ inch simulating a golf course putting green and $1 \frac{1 / 2}{2}$ inch simulating a golf course rough, respectively. Study 3 evaluated goosegrass control in creeping bentgrass at $1 / 8$ inch height. All studies were conducted as randomized complete blocks with a minimum of three replications per treatment and all studies were repeated in-time in 2009 and 2013 as subsequently described.

Treatments. Treatments evaluated for smooth crabgrass control were the same for both mowing heights and were metamifop (SAH001; Summit Agro International, Tokyo, Japan) applied once at 200,
400 , and $800 \mathrm{~g} \cdot \mathrm{ha}^{-1}$, metamifop applied in two sequential applications on a 3 -week interval at 200 or 400 $\mathrm{g} \cdot \mathrm{ha}^{-1}$, metamifop applied in three sequential applications on 3 -week intervals at 100 or $200 \mathrm{~g} \cdot \mathrm{ha}^{-1}$. Fenoxaprop (Acclaim Extra ${ }^{\circledR}$; Bayer Environmental Science, Research Triangle Park, NC) was included as a standard comparison and applied in three sequential applications on a 3-week interval at $17 \mathrm{~g} \cdot \mathrm{ha}^{-1}$ (note that these rates are below label recommendations). Smooth crabgrass control studies were initiated on 17 July, 10 Aug., and 25 Aug. 2009 for the first experimental repetition and 19 June 2013 for the second experimental repetition. In both 2009 and 2013 , smooth crabgrass growth stage was one to two tillers at the putting green height and three to five tillers at the rough height at the time of initial application. Smooth crabgrass control and creeping bentgrass injury data were collected $7,14,28,42$, and $56 \mathrm{~d}$ after initial treatment (DAIT). Twenty-eight DAIT corresponds to $7 \mathrm{~d}$ after second treatment, 42 DAIT corresponds to $21 \mathrm{~d}$ after second treatment, and 56 DAIT corresponds to $35 \mathrm{~d}$ after second treatment or $14 \mathrm{~d}$ after third treatment. All treatments were applied at $30 \mathrm{gal} /$ acre with a handheld four-nozzle boom [nozzles on $25-\mathrm{cm}$ spacing (TeeJet TJ8002VS; Spraying Systems, Wheaton, IL)] to $1.5 \times 1.5-\mathrm{m}$ plots.

Treatments evaluated for goosegrass control were metamifop applied once at 200,300, and $400 \mathrm{~g} \cdot \mathrm{ha}^{-1}$, and metamifop applied in two sequential applications on a 3 -week interval at 200 or $300 \mathrm{~g} \cdot \mathrm{ha}^{-1}$. Fenoxaprop was included as a standard comparison and applied once at $100 \mathrm{~g} \cdot \mathrm{ha}^{-1}$ and in two sequential applications on a 3 -week interval at $100 \mathrm{~g} \cdot \mathrm{ha}^{-1}$. Goosegrass control studies were initiated on 29 June and 20 July 2009 for experimental run 1 and 24 July and 19 Aug. 2013 for experimental run 2. Goosegrass growth stage was mostly $(\geq 75 \%)$ two to three tillers at the initial application for both experimental repetitions with the remaining plant at less mature growth stages. Goosegrass control was rated 7,21 , 42 , and 56 DAIT.

Measurements. Smooth crabgrass and goosegrass control were visually evaluated relative to the nontreated control on a 0 (no control) to 100 (complete plant necrosis) scale. Creeping bentgrass injury was visually evaluated using a similar 0 to 100 scale, with a score of 20 representing the maximum level of creeping bentgrass injury considered acceptable, similar to previous studies (Johnson, 1995, 1996; Johnson and Murphy, 1995).

EXPERIMENTAL DESIGN AND ANALYSIS. Data analyses were performed using PROC GLM (SAS version 9.1; SAS Institute, Cary, NC). Data were subjected to analysis of variance and effects were considered significant when $P<0.05$. Subsequently, data were subjected to means separation using Fisher's protected least significant difference $(P<0.05)$. All model assumptions were confirmed. In all studies, treatment and rating date were considered fixed effects whereas year was considered a random effect.

\section{Results and discussion}

SMOOTH CRABGRASS AT ROUGH HEIGHT. Smooth crabgrass control and creeping bentgrass injury data were pooled across years as the year by treatment interaction was not significant $(P>0.05)$. All metamifop treatments resulted in smooth crabgrass control greater than fenoxaprop at all rating dates (Table $\mathrm{l}$ ). Metamifop rates totaling $400 \mathrm{~g} \cdot \mathrm{ha}^{-1}$ or greater resulted in $\geq 80 \%$ smooth crabgrass control 56 DAIT. These data were consistent with those of Cox and Askew (2014), who found that $400 \mathrm{~g} \cdot \mathrm{ha}^{-1}$ resulted in $88 \%$ control at 8 weeks after treatment. Metamifop treatments applied sequentially at 3 -week intervals offered greater and more prolonged control (at 56 DAIT) than those applied only once, with the exception of the highest rate of $800 \mathrm{~g} \cdot \mathrm{ha}^{-1}$. Fenoxaprop applications resulted in $<50 \%$ control of smooth crabgrass. All treatments resulted in $<15 \%$ creeping bentgrass injury with applications of $800 \mathrm{~g} \cdot \mathrm{ha}^{-1}$ (whether sequential or one time) resulting in the greatest injury (Table 2). Cox and Askew (2014) reported no injury to any cool-season turfgrasses (not including creeping bentgrass) in studies, but made no conclusions because of lack of replication. Overall, metamifop at $200 \mathrm{~g} \cdot \mathrm{ha}^{-1}$ followed by $200 \mathrm{~g} \cdot \mathrm{ha}^{-1}$ resulted in the most economical combination of smooth crabgrass control (>95\% at 56 DAIT) and creeping 
bentgrass injury $(<15 \%)$ at the rough mowing height compared with fenoxaprop $(<49 \%$ control at 56 DAIT $)$.

SMOOTH CRABGRASS AT GREEN HEIGHT. At green mowing height, the year by treatment interaction was nonsignificant for smooth crabgrass control, so data were pooled across years. All metamifop treatments controlled smooth crabgrass greater than fenoxaprop at all rating dates (Table 3). All metamifop treatments resulted in $>90 \%$ smooth crabgrass control 28 DAIT, $>95 \%$ control 42 DAIT, and $\geq 94 \%$ control 56 DAIT. Fenoxaprop resulted in $<75 \%$ smooth crabgrass control throughout the trial. A single application of metamifop at $800 \mathrm{~g} \cdot \mathrm{ha}^{-1}$ resulted in $\geq 18 \%$ creeping bentgrass injury between 7 and 42 DAIT, with complete recovery by 56 DAIT (Table 4). The second application of $400 \mathrm{~g} \cdot \mathrm{ha}^{-1}$ in the sequential treatment resulted in $17 \%$ creeping bentgrass injury. Therefore, there is risk of creeping bentgrass injury associated with higher rates of metamifop, especially at low mowing heights. Sequential metamifop applications resulted in similar smooth crabgrass control with less creeping bentgrass injury compared with single applications. Based on these results, an effective regimen for smooth crabgrass control in a creeping bentgrass putting green is three applications of $100 \mathrm{~g} \cdot \mathrm{ha}^{-1}(98 \%$ control at 56 DAIT and 3\% injury at 56 DAIT) or a single application of $200 \mathrm{~g} \cdot \mathrm{ha}^{-1}$ (94\% control at 56 DAIT and no injury at 56 DAIT). Similar to this research, Post and Askew (2010) reported that metamifop controlled smooth crabgrass with $<10 \%$ creeping bentgrass injury, whereas comparable smooth crabgrass control with fenoxaprop completely killed creeping bentgrass putting greens. Comparing this with creeping bentgrass mowed at rough height, creeping bentgrass is more susceptible to metamifop injury at lower mowing heights.

GoosEgRAss. Year by treatment interactions were not significant for goosegrass control studies; accordingly, data were pooled. Metamifop at 200 followed by $200 \mathrm{~g} \cdot \mathrm{ha}^{-1}$ and 300 followed by $300 \mathrm{~g} \cdot \mathrm{ha}^{-1}$ resulted in $>89 \%$ goosegrass control 42 DAIT and 56 DAIT, respectively (Table 5). Fenoxaprop treatments resulted in similar to significantly less goosegrass control at 56 DAIT $(<74 \%)$ relative to

Table 1. Smooth crabgrass control comparing metamifop treatments and fenoxaprop at simulated roughs mowing height of $1 \frac{1 / 2}{\mathrm{inch}}(3.81 \mathrm{~cm})$ pooled over experiments in 2009 and 2013 in Auburn, AL.

\begin{tabular}{lccccc}
\hline & & 14 DAIT $^{\mathbf{y}}$ & 28 DAIT & 42 DAIT & 56 DAIT \\
\cline { 3 - 6 } Herbicide & Rate $\left(\mathbf{g} \cdot \mathbf{h a}^{-\mathbf{1}}\right)^{\mathbf{z}}$ & \multicolumn{4}{c}{ \% control } \\
Metamifop & 200 & 65 & 65 & 59 & 64 \\
Metamifop & 400 & 75 & 83 & 82 & 80 \\
Metamifop & 800 & 94 & 95 & 95 & 93 \\
Metamifop & $200 \mathrm{fb} \mathrm{200}$ & 68 & 90 & 96 & 98 \\
Metamifop & $400 \mathrm{fb} \mathrm{400}$ & 92 & 96 & 100 & 100 \\
Metamifop & $200 \mathrm{fb} \mathrm{200} \mathrm{fb} \mathrm{200}$ & 81 & 92 & 97 & 98 \\
Metamifop & $100 \mathrm{fb} \mathrm{100} \mathrm{fb} \mathrm{100}$ & 60 & 67 & 72 & 91 \\
Fenoxaprop & $17 \mathrm{fb} 17 \mathrm{fb} \mathrm{17}$ & 23 & 25 & 39 & 49 \\
LSD $_{(0.05)}{ }^{\mathbf{x}}$ & & 28 & 16 & 11 & 5 \\
\hline
\end{tabular}

LSD = least significant difference.

${ }^{2}$ Sequential treatments were applied on 3 -week intervals; $1 \mathrm{~g} \cdot \mathrm{ha}^{-1}=0.0143 \mathrm{oz} / \mathrm{acre}, \mathrm{fb}=$ followed by y Days after initial treatment.

${ }^{x}$ LSD with a $95 \%$ confidence interval.

Table 2. Creeping bentgrass injury from metamifop at various rates and application regimes at simulated roughs mowing height of $1^{1 / 2}$ inch $(3.81 \mathrm{~cm})$ in 2009 and 2013 in Auburn, AL.

\begin{tabular}{|c|c|c|c|c|c|}
\hline \multirow[b]{2}{*}{ Herbicide } & \multirow[b]{2}{*}{ Rate $\left(\mathrm{g} \cdot \mathrm{ha} \mathrm{a}^{-1}\right)^{\mathrm{z}}$} & 7 DAIT $^{\mathrm{y}}$ & 14 DAIT & 28 DAIT & 42 DAIT \\
\hline & & \multicolumn{4}{|c|}{$\%$ injury } \\
\hline Metamifop & 200 & 0 & 0 & 2 & 0 \\
\hline Metamifop & 400 & 1 & 0 & 4 & 3 \\
\hline Metamifop & 800 & 13 & 13 & 12 & 10 \\
\hline Metamifop & $200 \mathrm{fb} 200$ & 0 & 0 & 6 & 7 \\
\hline Metamifop & $400 \mathrm{fb} 400$ & 4 & 0 & 10 & 9 \\
\hline Metamifop & $200 \mathrm{fb} 200 \mathrm{fb} 200$ & 3 & 0 & 4 & 2 \\
\hline Metamifop & $100 \mathrm{fb} 100 \mathrm{fb} 100$ & 0 & 0 & 3 & 0 \\
\hline Fenoxaprop & $17 \mathrm{fb} 17 \mathrm{fb} 17$ & 1 & 0 & 0 & 0 \\
\hline $\operatorname{LSD}_{(0.05)}{ }^{\mathrm{x}}$ & & 5 & NS & 5 & 7 \\
\hline
\end{tabular}

LSD $=$ least significant difference.

${ }^{2}$ Sequential treatments were applied on 3-week intervals; $1 \mathrm{~g} \cdot \mathrm{ha}^{-1}=0.0143 \mathrm{oz} / \mathrm{acre}, \mathrm{fb}=$ followed by . yDays after initial treatment.

${ }^{\mathrm{x}}$ LSD with a $95 \%$ confidence interval; NS = not significant.

Table 3. Smooth crabgrass control comparing metamifop and fenoxaprop at simulated greens mowing height of $1 / 8$ inch $(3.18 \mathrm{~mm})$ pooled over experiments in 2009 and 2013 in Auburn, AL.

\begin{tabular}{lccccc}
\hline & & 14 DAIT $^{\mathbf{y}}$ & 28 DAIT & 42 DAIT & 56 DAIT \\
\cline { 3 - 6 } Herbicide & Rate $\left(\mathbf{g} \cdot \mathbf{h a}^{-\mathbf{1}}\right)^{\mathbf{z}}$ & \multicolumn{4}{c}{ \% control } \\
Metamifop & 200 & 93 & 96 & 96 & 94 \\
Metamifop & 400 & 99 & 100 & 99 & 96 \\
Metamifop & 800 & 99 & 100 & 99 & 96 \\
Metamifop & $200 \mathrm{fb} \mathrm{200}$ & 92 & 96 & 98 & 99 \\
Metamifop & $400 \mathrm{fb} \mathrm{400}$ & 97 & 99 & 99 & 100 \\
Metamifop & $200 \mathrm{fb} \mathrm{200} \mathrm{fb} \mathrm{200}$ & 95 & 98 & 99 & 98 \\
Metamifop & $100 \mathrm{fb} \mathrm{100} \mathrm{fb} \mathrm{100}$ & 86 & 91 & 99 & 98 \\
Fenoxaprop & $17 \mathrm{fb} \mathrm{17} \mathrm{fb} \mathrm{17}$ & 52 & 62 & 69 & 74 \\
LSD $_{(0.05)}{ }^{\mathbf{x}}$ & & 8 & 6 & 7 & 10 \\
\hline
\end{tabular}

LSD $=$ least significant difference.

${ }^{\mathrm{z}}$ Sequential treatments were applied on 3 -week intervals; $1 \mathrm{~g} \cdot \mathrm{ha}^{-1}=0.0143 \mathrm{oz} / \mathrm{acre}, \mathrm{fb}=$ followed by y Days after initial treatment.

${ }^{x}$ LSD with a $95 \%$ confidence interval.

the best metamifop treatments (>90\%). These data indicate that metamifop at 300 followed by $300 \mathrm{~g} \cdot \mathrm{ha}^{-1}$ was the best treatment for goosegrass control.
Metamifop applied sequentially at 300 followed by $300 \mathrm{~g} \cdot \mathrm{ha}^{-1}$ does pose injury risk to creeping bentgrass greens, therefore timing is important 
Table 4. Creeping bentgrass injury from metamifop at various rates and application regimes at simulated greens mowing height of $1 / 8$ inch $(3.18 \mathrm{~mm})$ in 2009 and 2013 in Auburn, AL.

\begin{tabular}{|c|c|c|c|c|c|c|}
\hline & & 7 DAIT $^{y}$ & 14 DAIT & 28 DAIT & 42 DAIT & 56 DAIT \\
\hline Herbicide & Rate $\left(\mathrm{g} \cdot \mathrm{ha} \mathrm{a}^{-1}\right)^{\mathrm{z}}$ & & & $\%$ injury & & \\
\hline Metamifop & 200 & 1 & 0 & 1 & 0 & 0 \\
\hline Metamifop & 400 & 9 & 3 & 6 & 1 & 0 \\
\hline Metamifop & 800 & 22 & 23 & 18 & 19 & 1 \\
\hline Metamifop & $200 \mathrm{fb} 200$ & 0 & 0 & 0 & 5 & 3 \\
\hline Metamifop & $400 \mathrm{fb} 400$ & 9 & 4 & 7 & 17 & 8 \\
\hline Metamifop & $200 \mathrm{fb} 200 \mathrm{fb} 200$ & 4 & 1 & 2 & 6 & 4 \\
\hline Metamifop & $100 \mathrm{fb} 100 \mathrm{fb} 100$ & 2 & 0 & 1 & 0 & 3 \\
\hline Fenoxaprop & $17 \mathrm{fb} 17 \mathrm{fb} 17$ & 5 & 0 & 0 & 1 & 0 \\
\hline $\operatorname{LSD}_{(0.05)^{x}}$ & & 6 & 3 & 6 & 4 & NS \\
\hline
\end{tabular}

LSD = least significant difference.

${ }^{2}$ Sequential treatments were applied on 3 -week intervals; $1 \mathrm{~g} \cdot \mathrm{ha}^{-1}=0.0143 \mathrm{oz} / \mathrm{acre}, \mathrm{fb}=$ followed by. 'Days after initial treatment.

${ }^{\mathrm{x}}$ LSD with a $95 \%$ confidence interval; $\mathrm{NS}=$ not significant

Table 5. Goosegrass control from metamifop at various rates and application regimes in 2009 and 2013 in Auburn, AL.

\begin{tabular}{lccccc}
\hline & & 7 DAIT $^{\mathrm{y}}$ & 21 DAIT & 42 DAIT & 56 DAIT \\
\cline { 3 - 6 } Herbicide & Rate $\left(\mathbf{g} \cdot \mathbf{h a}^{-\mathbf{1}}\right)^{\mathbf{z}}$ & \multicolumn{4}{c}{ \% control } \\
\hline Metamifop & 200 & 33 & 63 & 50 & 57 \\
Metamifop & 300 & 42 & 72 & 68 & 73 \\
Metamifop & 400 & 45 & 76 & 75 & 81 \\
Metamifop & $200 \mathrm{fb} 200$ & 34 & 58 & 89 & 91 \\
Metamifop & $300 \mathrm{fb} \mathrm{300}$ & 31 & 81 & 99 & 100 \\
Fenoxaprop & 100 & 39 & 60 & 52 & 40 \\
Fenoxaprop & $100 \mathrm{fb} 100$ & 38 & 58 & 87 & 74 \\
LSD $_{(0.05)}{ }^{\mathrm{x}}$ & & 8 & 17 & 10 & 14 \\
\hline
\end{tabular}

LSD = least significant difference.

${ }^{2}$ Sequential treatments were applied on 3 -week intervals; $1 \mathrm{~g} \cdot \mathrm{ha}^{-1}=0.0143 \mathrm{oz} / \mathrm{acre}, \mathrm{fb}=$ followed by

Days after initial treatment.

${ }^{x}$ LSD with a $95 \%$ confidence interval.

when choosing a second application date. An alternative is to apply 200 followed by $200 \mathrm{~g} \cdot \mathrm{ha}^{-1}$, which provides good goosegrass control with less injury potential to creeping bentgrass than fenoxaprop, as well as decreased cost in amount of product used.

\section{Summary}

Compared with current herbicide options for smooth crabgrass and goosegrass control, metamifop offers comparable control with less threat of cool-season grass injury (Derr et al., 1985; Neal et al., 1990; Warren et al., 1989). Metamifop can effectively control smooth crabgrass POST at both rough and putting green mowing heights without injury to creeping bentgrass. In addition, goosegrass can be effectively controlled POST in a creeping bentgrass putting green, although higher rates are required compared with smooth crabgrass. Generally, metamifop applied sequentially resulted in greater smooth crabgrass and goosegrass control and creeping bentgrass safety relative to single applications. POST metamifop applications along with currently used PRE options such as bensulide and siduron will allow for greater smooth crabgrass and goosegrass control with the added benefit of multiple modes of action to decrease the likelihood of herbicide resistance in creeping bentgrass systems. Multiple applications of metamifop totaling 300 to $600 \mathrm{~g} \cdot \mathrm{ha}^{-1}$ will provide good control of smooth crabgrass and goosegrass, especially after late flushes of these troublesome weeds, with limited risk of creeping bentgrass injury. Future research may focus on further refining metamifop rates and timings or possible differences in creeping bentgrass tolerance by variety.

\section{Literature cited}

Burton, J.D., J.W. Gronwald, D.A. Somers, J.A. Connelly, B.G. Gengenbach, and D.L. Wyse. 1987. Inhibition of plant acetyl-coenzyme A carboxylase by the herbicides sethoxydim and haloxyfop. Biochem. Biophys. Res. Commun. 148:1039-1044

Busey, P. 2003. Cultural management of weeds in turfgrass: A review. Crop Sci. 43:1899-1911.

Callahan, L.M. 1986. Crabgrass and goosegrass control in a bentgrass green in the transition zone. Agron. J. 78:625-628.

Cox, M.C. and S.D. Askew. 2014. Metamifop rates, application timings, and broadleaf herbicide admixtures affect smooth crabgrass control in turf. Weed Technol. 28:617-625.

Cudney, D.W., C.L. Elmore, V.A. Gibeault, and J.S. Reints. 1997. Common bermudagrass (Cynodon dactylon) management in cool-season turfgrass. Weed Technol. 11:478-483.

Dernoeden, P.H. 1987. Tolerance of perennial ryegrass and tall fescue seedlings to fenoxaprop. Agron. J. 79:1035-1037.

Derr, J.F., T.J. Monaco, and T.J. Sheets. 1985. Response of three annual grasses to fluazifop. Weed Sci. 33:693-697.

Devine, M., S.O. Duke, and C. Fedtke. 1993. Physiology of herbicide action. Prentice Hall, Englewood Cliffs, NJ.

Flessner, M.L. and J.S. McElroy. 2011. Potential use of metamifop for weed control in turfgrass. Proc. Amer. Soc. Agron./Crop Sci. Soc. Amer./Soil Sci. Soc. Amer. Intl. Annu. Mtg., San Antonio, TX. Abstr. 328-6.

Focke, M. and H.K. Lichtenthaler. 1987. Inhibition of the acetyl-CoA carboxylase of barley chloroplasts by cycloxydim and sethoxydim. Verlag der Zeitschrift für Naturforschung. 42:1361.

Hart, S.E., D.W. Lycan, and J.A. Murphy. 2004. Use of quinclorac for large crabgrass (Digitaria sanguinalis) control in newly summer-seeded creeping bentgrass (Agrostis stolonifera). Weed Technol. 18:375-379.

Heap, I. 2015. The International Survey of Herbicide Resistant Weeds. 30 Sept. 2015. <http://weedscience.org/ summary/species.aspx?WeedID $=177>$.

Hoyle, J.A., C. Straw, G. Henry, J. Brosnan, and G. Breeden. 2012. Efficacy of metamifop for the control of large crabgrass at various growth stages. Proc. Amer. Soc. Agron./Crop Sci. Soc. Amer./Soil Sci. Soc. Amer. Intl. Annu. Mtg. San Antonio, TX. Abstr. 105-8. 
Johnson, B.J. 1995. Tolerance of four seeded common bermudagrass (Cynodon dactylon) types to herbicides. Weed Technol. 9:794-800.

Johnson, B.J. 1996. Tank-mixed postemergence herbicides for large crabgrass (Digitaria sanguinalis) and goosegrass (Eleusine indica) control in bermudagrass (Cynodon dactylon) turf. Weed Technol. 10:716-721.

Johnson, B.J. and T.R. Murphy. 1995. Effect of paclobutrazol and flurprimidol on suppression of Poa annua spp. reptans in creeping bentgrass (Agrostis stolonifera) greens. Weed Technol. 9:182-186.

Kim, T.J., H.S. Chang, J.W. Ryu, Y.K. Ko, D.W. Kim, K.Y. Cho, C.H. Park, O.Y. Kwon, and B.J. Chung. 2003a. Metamifop: A new post-emergence grass killing herbicide for use in rice. Proc. Brit. Crop Production Council Intl. Congr., Crop Sci. Technol., Vol. 1 and 2. Glasgow, Scotland, UK, p. 81-86.

Kim, T.J., H.S. Chang, J.S. Kim, I.T. Hwang, K.S. Hong, D.W. Kim, K.Y. Cho, E.J. Myung, and B.J. Chung. 2003b. Metamifop: Mechanism of herbicidal activity and selectivity in rice and barnyardgrass. Proc. Brit. Crop Production Council Intl. Congr., Crop Sci. Technol.,
Vol. 1 and 2. Glasgow, Scotland, UK, p. 833-838.

King, J.W. 1990. Fenoxaprop for crabgrass and goosegrass control in turfgrasses. AR Farm Res. 39:7.

Moon, J.K., Y.S. Keum, E.C. Hwang, B.S. Park, H.R. Chang, Q.X. Li, and J.H. Kim. 2007. Hapten syntheses and antibody generation for a new herbicide, metamifop. J. Agr. Food Chem. 55:5416-5422.

Moon, J.K., J.H. Kim, and T. Shibamoto. 2010. Photodegradation pathways and mechanisms of the herbicide metamifop in a water/acetonitrile solution. J. Agr. Food Chem. 58:12357-12365.

Mudge, L.C., B.J. Gossett, and T.R. Murphy. 1984. Resistance of goosegrass (Eleusine indica) to dinitroaniline herbicides. Weed Sci. 32:591-594.

Mueller-Warrant, G.W. 1990. Control of roughstalk bluegrass (Poa trivialis) with fenoxaprop in perennial ryegrass (Lolium perenne) grown for seed. Weed Technol. $4: 250-257$.

Neal, J.C., P.C. Bhowmik, and A.F. Senesac. 1990. Factors influencing fenoxaprop efficacy in cool-season turfgrass. Weed Technol. $4: 272-278$.
Parker, N.Y., T.J. Monaco, R.B. Leidy, and T.J. Sheets. 1985. Weed control with fluazifop and residues in cucurbit crops (Cucumis sp.) and sweet potatoes (Ipomoea batatas). Weed Sci. 33:405-410.

PBI/Gordon Corp. 2009. Bensumec ${ }^{\text {TM }} 4$ LF herbicide product label. PBI/Gordon Publ. no. 845/8-2009.

Post, A.R. and S.D. Askew. 2010. Coolseason turfgrass tolerance and weed control efficacy of metamifop. Korean Soc. Pesticide. Sci. 10:50-51.

Quali-Pro. 2013. Oxadiazon SC ${ }^{\circledR}$ QualiPro product label. Quali-Pro Publ. no. 13414.

Senseman, S.A. (ed.). 2007. Herbicide handbook. 9th ed. Weed Sci. Soc. Amer. Champaign, IL.

Stoltenberg, D.E., J.W. Gronwald, D.L. Wyse, J.D. Burton, D.A. Somers, and B. G. Gengenbach. 1989. Effect of sethoxydim and haloxyfop on acetyl-coenzyme A carboxylase activity in Festuca species. Weed Sci. 37:512-516.

Warren, S.L., W.A. Skroch, T.J. Monaco, and J.M. Shribbs. 1989. Tolerance of five perennial cool-season grasses to fluazifop. Weed Technol. 3:385-388. 